\title{
Experimental Plan for the Cold Demonstration (Scoping Tests) of Glass Removal Methods from a DWPF Melter (U)
}

Michael E. Smith

Westinghouse Savannah River Company

Savannah River Technology Center

Aiken, SC 29808

Westinghouse Savannah River Company 
This document was prepared in conjunction with work accomplished under Contract No.

DE-AC09-96SR18500 with the U.S. Department of Energy.

\section{DISCLAIMER}

This report was prepared as an account of work sponsored by an agency of the United States Government. Neither the United States Government nor any agency thereof, nor any of their employees, makes any warranty, express or implied, or assumes any legal liability or responsibility for the accuracy, completeness, or usefulness of any information, apparatus, product or process disclosed, or represents that its use would not infringe privately owned rights. Reference herein to any specific commercial product, process or service by trade name, trademark, manufacturer, or otherwise does not necessarily constitute or imply its endorsement, recommendation, or favoring by the United States Government or any agency

thereof. The views and opinions of authors expressed herein do not necessarily state or reflect those of the United States Government or any agency thereof.

This report has been reproduced directly from the best available copy.

Available for sale to the public, in paper, from: U.S. Department of Commerce, National Technical Information Service, 5285 Port Royal Road, Springfield, VA 22161, phone: (800)

553-6847, fax: (703) 605-6900, email: orders@ntis.fedworld.gov online ordering: http://www.ntis.gov/ordering.htm

Available electronically at http://www.doe.gov/bridge

Available for a processing fee to U.S. Department of Energy and its contractors, in paper, from: U.S. Department of Energy, Office of Scientific and Technical Information, P.O. Box 62, Oak Ridge, TN 37831-0062, phone: (865 ) 576-8401, fax: (865) 576-5728, email: reports@ adonis.osti.gov 
WSRC-RP-2001-00783

Publication Date: September 15, 2001

\section{Experimental Plan for the Cold Demonstration (Scoping Tests) of Glass Removal Methods from a DWPF Melter (U)}

Michael E. Smith

Westinghouse Savannah River Company

Savannah River Technology Center

Aiken, SC 29808

Westinghouse Savannah River Company 
WSRC-RP-2001-00783

\section{INTRODUCTION}

SRS and WVDP currently do not have the capability to size reduce, decontaminate, classify, and dispose of large, failed, highly contaminated equipment. Tanks Focus Area Task 777 (Remote Disassembly of HLW Melters and Other Processing Equipment) was developed to address this problem. Probably the most problematic pieces of High Level Waste (HLW) equipment to dispose of are the melters. They are large, heavy, complicated pieces of equipment that can contain a large amount of HLW glass (up to about 15,000 pounds for the DWPF melter). The current approach to dealing with the melter at the DWPF is long term storage in failed equipment storage vaults. While storage is acceptable in the short term, technology must be developed to properly dispose of these melters.

\section{DEMONSTRATION OBJECTIVE}

The first activity for Task 777 is to develop and demonstrate techniques suitable for removing the solid HLW glass from HLW melters. As part of this activity, techniques to dismantle some components of the melter will be tested as well. This experimental plan describes the work that will be performed for this glass removal demonstration.

\section{BACKGROUND}

As part of Task 777, the Oak Ridge National Laboratory ${ }^{1}$, West Valley Demonstration Project $^{2}$, and the Savannah River Technology Center ${ }^{3}$ have written several reports on the removal of glass from HLW melters as well as the dismantlement of these melters. After review of these reports and details of the DWPF Melter, the conclusion was made that removal of glass from a DWPF Melter with the lid still on would be quite difficult. This determination probably takes away the option of trying to repair a DPWF Melter that has failed (or is failing) from noble metals deposits. This conclusion is based on the fact that the two large nozzle openings (8-inch off-gas and backup off-gas nozzles) have the melter dome heaters located directly below them, thereby preventing the use of these two nozzles for glass removal access. The other melter top-head nozzles as fairly small as they have inner diameters less than 4 inches. These nozzles were deemed too small to use for access ports for glass removal. Another driver to remove the melter lid is that there should be a fairly significant buildup of deposits on the inside of the melter lid. These deposits should be removed as much as possible to allow the disposal of the melter as non-HLW or TRU. Therefore the current position of the TFA Task 777 Principle Investigator is that the most prudent glass removal technique of a failed melter is as follows:

- remove the melter lid

- cut the dome heaters out

- remove the melt pool glass

- remove as much glass as possible from the surface of the K-3 glass contact refractory

- remove as much of the deposits as possible from the melter lid

- replace the melter lid and store the melter as non-HLW. 
It is the current position of DWPF to remove as much glass as possible from the melter if there are signs that the melter is close to becoming inoperable for melter feeding and pouring. This was quite evident during DWPF Melter operational problems which occurred in July 2001 that were fortunately quickly resolved (a dummy Hanford connector dropped about 18 months ago was beginning to short a lower electrode bus bar). Plans were underway to pour as much glass out the melter via the riser/pour spout with higher than normal melter/pour spout differential pressures. This would have lowered the melt pool level to the top of the riser entrance and left less than 2 canisters worth of glass in the melter. The melter would have been further emptied via the melter drain valve, which if operating correctly would have left only a few inches of glass/spinels/noble metals on the bottom of the melter (approximately 400 to 800 pounds).

\section{TEST STRATEGY}

The following tasks are needed to remove glass from the melter via the lid removal strategy (see pages 19 and 20 of WSRC-TR-2001-00248 ${ }^{3}$ ) will be tested in a three staged approach:

- top lid bolt cutting

- cutting and removal of dome heaters

- removal of deposits from inside of melter lid

- glass breakup/removal from melt pool

- glass removal from K-3 refractory surfaces

- K-3 refractory breakup (not needed for glass removal strategy but will be required if total melter dismantlement is performed in future - is not required for this demonstration).

\section{Scoping Tests at HCET}

The first stage of testing will be scoping tests to be performed by Florida International University's (FIU) Hemispheric Center for Environmental Technology (HCET) with guidance from the SRTC TFA Task 777 Principle Investigator. ORNL and WVPD personnel involved with this TFA task may be present during these tests as well. The attached HCET proposal will be used to perform the test. Further test details are given in this proposal. Not all of the tasks to be tested in the other two stages will be tested by HCET. These scoping tests will be comprised of the testing of these three tasks:

- glass breakup (jack hammer/chisel, needle gun)

- glass removal from K-3 refractory surfaces (diamond wheel shaver, needle scaler, rotary tool with a face grinding wheel, and needle gun)

- K-3 refractory breakup (jack hammer/chisel, rotary tool with face grinding wheel).

The tools tested will be hand tools. Adaptation to remote operations will be determined/ investigated in the next two test stages. After completion of the tests, HCET will write a report on the performance of the test, results, and recommendations. The report will be reviewed by the SRTC Task Principle Investigator as well as by WVDP and ORNL Robotics personnel per guidance from the Principle Investigator. 
WSRC-RP-2001-00783

NOTE: The PI may choose other tools to test during this or the other stages of the demonstration. The choices will be documented to the test site personnel. The main activities of this testing stage are to procure tooling (if not available) for each task listed above, modify the tooling for remote operation as required, and then test the equipment for remote operability. Performance testing of the equipment will be done as well. Full mockups of a melter or portions of a melter will not be used for this part of the tests.

Interface Testing

After completion of the HCET scoping tests, the Principle Investigator, with input from the appropriate WVDP, ORNL, and SRS personnel, will choose tools (possible tools noted in parentheses) to test for the following tasks as listed in the Test Strategy section of this experimental plan:

- top lid bolt cutting (rotary tool with face grinding wheel, plasma torch)

- cutting and removal of dome heaters (rotary tool with face grinding wheel, band saw, circular saw, heavy duty metal cutters, plasma torch)

- removal of deposits from inside of melter lid (diamond wheel shaver, needle scaler, rotary tool with a face grinding wheel, needle gun)

- glass breakup/removal from melt pool (jack hammer/chisel, needle gun)

- glass removal from K-3 refractory surfaces (diamond wheel shaver, needle scaler, rotary tool with a face grinding wheel, needle gun)

- K-3 refractory breakup (jack hammer/chisel, rotary tool with face grinding wheel not needed for glass removal strategy chosen but will be required if total melter dismantlement is required in future).

Remote Demonstration

After completion of the Interface Testing stage of the demonstration, a full or partial mockup of a DWPF Melter is needed to test the remote operation of the tools chosen from the first two stages. If possible, a pilot scale melter such as the Scale Glass Melter (SGM) could be used. The SGM is a non-radioactive $2 / 3$ scale pilot DWPF melter. It has a 4foot inner diameter with 8-inch thick K-3 refractory. It is the closest pilot scale melter to the DWPF Melter with regards to size, configuration, and materials of construction.

The SGM is currently being stored at DWPF and could be still operated as a research melter for DWPF or in support of other DOE sites such as INEEL or Hanford. Due to this possible future use, no destructive tests would be performed on it (cutting of dome/lid heaters, K-3 refractory breakup). The SGM would be an excellent melter to use as it has deposits on the melter lid refractory as well as the K-3 refractory. Remote removal of the melter lid could be tested as well. Below is a table that compares the dimensions and other features of the SGM and the DWPF Melter. ${ }^{4,5}$ Figures 1 and 2 give cross-sectional views of both of these melters. 
WSRC-RP-2001-00783

Table 1 - Comparison of DWPF Melter and Scale Glass Melter

\begin{tabular}{|l|c|c|}
\hline \multicolumn{1}{|c|}{ ITEM } & DWPF & SGM \\
\hline Melter inner diameter/melt area & $6 \mathrm{ft} / 24.7 \mathrm{ft}^{2}$ & $4 \mathrm{ft} / 11.8 \mathrm{ft}^{2}$ \\
\hline Overall height (top head flange to drain valve) & $10.75 \mathrm{ft}$ & $8.6 \mathrm{ft}$ \\
\hline Distance from melt pool to off-gas vent & $40 \mathrm{in}$ & $38 \mathrm{in}$ \\
\hline Glass pool height (full) & $37 \mathrm{in}$ & $27 \mathrm{in}$ \\
\hline Melter shell material of construction & $304 \mathrm{~L}$ SS & $304 \mathrm{~L} \mathrm{SS}$ \\
\hline Melter shell thickness & 1.12 to 3 in & 1.12 to 2 in \\
\hline Electrode material of construction & Inconel 690 & Inconel 690 \\
\hline Distance between electrodes & 56 in & 37.5 in \\
\hline Glass contact refractories & Monofrax K-3 & Monofrax K-3 \\
\hline Glass contact refractory thickness & 12 in & 8 in \\
\hline Vapor space refractory & Korundal XD & $*$ Mullfrax 202 \\
\hline Refractory below floor & Zirmul & Zirmul \\
\hline Lid heaters material of construction & Inconel 690 & Inconel 690 \\
\hline Lid heaters outer diameter/wall thickness & 3.25 in / 0.5 in & 3.25 in / 0.5 in \\
\hline
\end{tabular}

*Mullfrax 202 is similar in composition to Korundal XD

The SGM is an excellent candidate melter for this work. Therefore the SGM will be used unless other factors outside the control of the PI do not allow the melter to be used. The SGM had its top head components removed and most of the glass was emptied out of it via the bottom drain valve before it was shutdown in 1988. There is a thin layer of glass still on the melter floor. The melter frame footing is about 9 feet by 9 feet and the melter is about 15 feet tall on the frame. The frame is rated for 44,000 pounds. The following section gives further details on the Remote Testing stage of this demonstration. If deemed necessary, the SGM could be used in the future for a full dismantlement demonstration that is not currently funded for TFA Task 777 . 
WSRC-RP-2001-00783

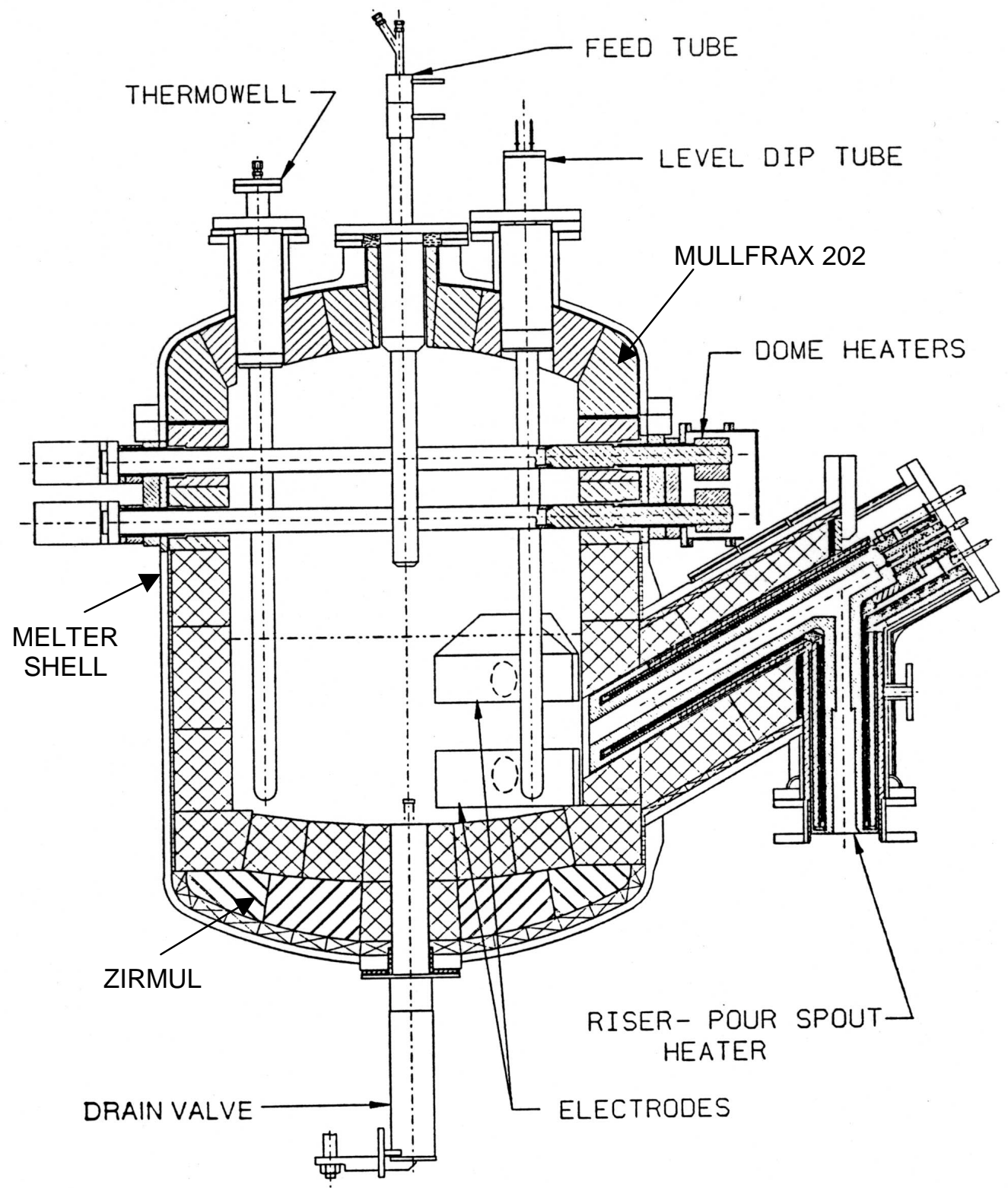

Figure 1 - Scale Glass Melter (Cross-section) 
WSRC-RP-2001-00783

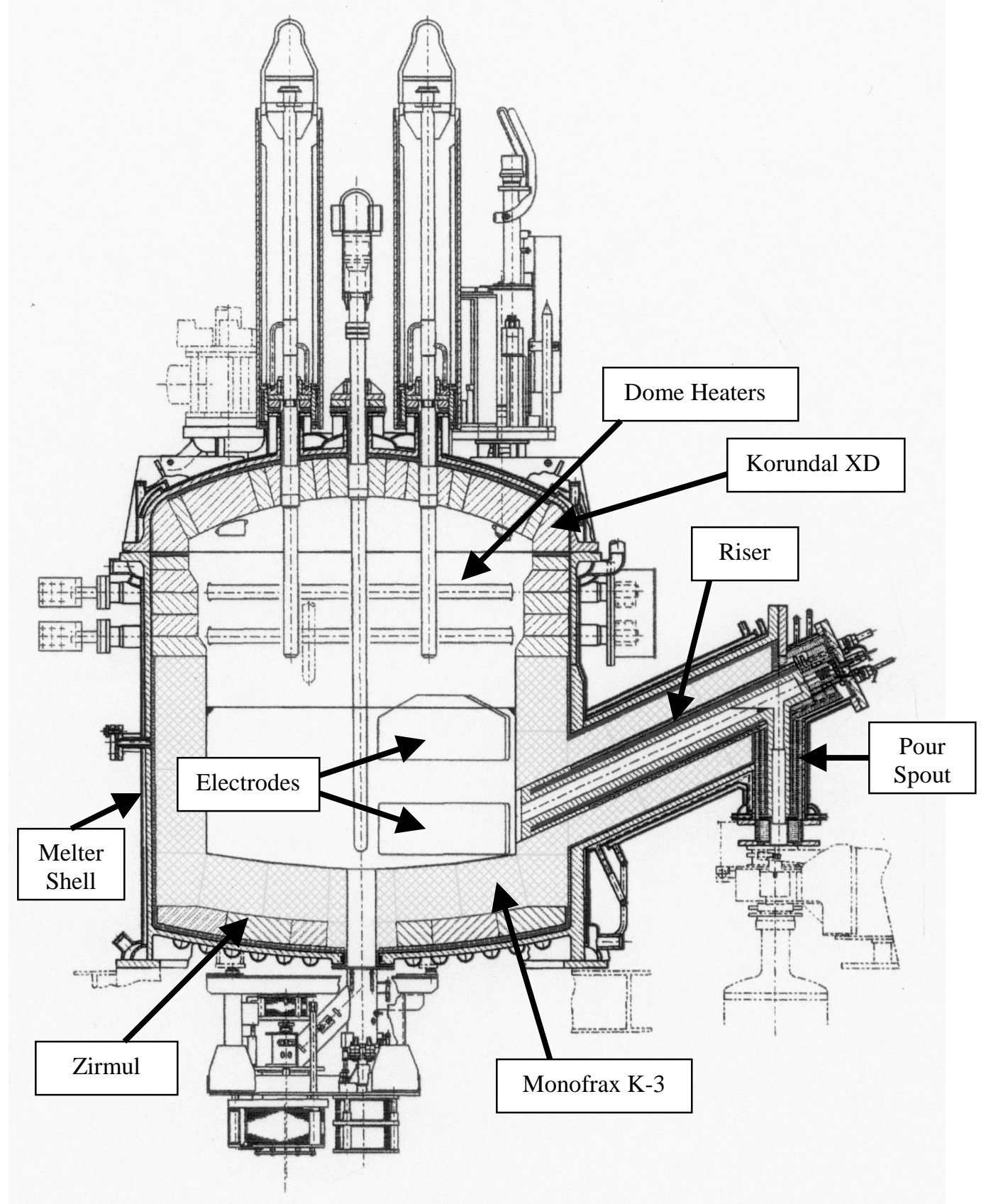

Figure 2 - DWPF Melter (Cross-section) 
WSRC-RP-2001-00783

\section{OVERALL REMOTE DEMONSTRATION STAGE REQUIRMENTS}

As discussed before, the following tasks will be tested in the remote demonstration stage:

- top lid bolt cutting

- cutting and removal of dome heaters

- removal of deposits from inside of melter lid

- glass breakup/removal from melt pool

- glass removal from K-3 refractory surfaces

- K-3 refractory breakup (not needed for glass removal strategy chosen but will be required if total melter dismantlement is performed in future - is not required for this demonstration).

The current plan is to use the Scale Glass Melter. Any tasks performed on the SGM must be done in a manner that leaves the melter in a post test condition so that it could be operated for future vitrification operation tests. Therefore the cutting and removal of the dome heaters and the K-3 refractory breakup could not be performed on the SGM. These tasks will be mocked up as described in the appropriate task description sections.

Overall Site Requirements

The test site should have a high bay area (at least 40 feet high) that allows for remote testing. The test floor space area should be at least 25 feet by 25 feet. A larger floor space would make the work easier. An overhead bridge is required with hoists with at least 5 ton lifting capability. A manipulator capable of performing the described work below is also needed. Additional systems such as a transporter with a telescoping mast could be useful as well. Utilities such as compressed air, electricity, water, and remote viewing capabilities are needed as well.

Demonstration Preparations

The following tasks are required before performing the remote demonstration:

- approval of this demonstration plan

- shipment of SGM to test site or fabrication of DWPF Melter mockup at test site (mockup would be designed and fabricated by test site with agreement by PI)

- shipment of lid heater test piece and K-3 refractory to test site

- ensure functionality of remote test equipment

- completion of FIU scoping tests

- sufficient completion of interface testing

- documented agreement of tools of choice to be tested for each task (PI and demonstration site)

- procurement, receipt, and checkout of remote tools (should be done for most tools in interface testing stage)

- review of the latest revision of this demonstration plan between PI and demonstration site personnel

Guidelines for Performance of Remote Demonstration

Test site personnel will perform the Remote Demonstration per this demonstration plan. The latest version of the demonstration plan will be available at the test site during the 
demonstration work. The TFA Task 777 PI will be present during all stages of the demonstration unless the PI gives approval to proceed. Task 777 personnel from WVDP, ORNL, SRTC, as well as DWPF Melter personnel are encouraged to be present at key points in the demonstration.

Documentation of the testing will be via pictures, video recording, and logging of results in the designated task notebook provided by the PI. Normally the PI or his designee will enter this information into the task notebook. Test observations such as ease of performance of task, time needed to perform task, equipment problems, wear of equipment (blades, etc), unexpected problems, etc will be noted in the designated task notebook. Pictures and video should be digital for ease of transmittal and for use in the demonstration report. Pictures and video will be provided in a timely manner to the PI. Decisions made between the PI and test site personnel should be documented in the designated task notebook.

During the remote demonstration (and if possible during the Scoping and Interface Testing stages) the following additional data should be taken (when appropriate) for the tools tested:

- airborne particulate generation (concern is for plugging HEPA filters in facility that glass removal from radioactive melters is actually performed)

- live and dead loads that tools put on manipulators

- if possible, determine the amplitude of vibrations that the tooling causes

\section{REMOTE DEMONSTRATION STAGE REQUIRMENTS PER TASK}

Below are the details of the various glass removal tasks. Unless otherwise stated, these tasks are to be performed remotely on the Scale Glass Melter or the to-be-determined DWPF Melter mockup. These tasks should be performed in the order that they are listed to better simulate remote glass removal from a DWPF Melter.

\section{1) Top Lid Bolt Cutting}

The lid bolts on the SGM, unlike those on the DWPF Melter, are not tack-welded in place. The same type of techniques (grinding or cutting) will be required. The most likely tools to be tested are a rotary tool with a face grinding wheel or a plasma torch. Care must be taken as to not to damage the lid or melter shell beyond the point that it could be reused for vitrification tests. Not all of the bolts will be remotely removed. After a sufficient number of bolt cutting tests has been performed (probably eight or less), the remaining bolts will be removed manually. Bolts at different positions should be removed with the various techniques to determine if there are any problems with regards to orientation.

Note: Although not specified as a task, the remote removal of the melter lid shall be attempted. The lid, which was not designed for remote removal/handling, has no lifting eyes or lugs. An approach for lifting the lid should be devised and tested at this point. There is the possibility that the lid refractories were removed when the SGM was shut down and inspected in the late 1980's. 
WSRC-RP-2001-00783

\section{2) Cutting and Removal of Dome (Lid) Heaters}

The 3.25 inch outer diameter Inconel 690 dome heaters in the SGM cannot be cut, as the melter may be needed for possible future vitrification work. Therefore the dome heaters will be manually removed and a replacement bar of Inconel 690 will be manually installed. Due to the need for three-inch Inconel 690 bar by DWPF for pour spout insert fabrication, a two-inch bar may be used. If Inconel 690 bar is not available, a bar of another metallic composition as chosen by the PI may be installed, cut, and removed. The most likely tools to be tested are a rotary tool with a face grinding wheel, band saw, circular saw, heavy-duty metal cutters, or a plasma torch. A device to hold the bar during cutting will be needed to prevent it from falling into the melter. The cutting should be done as close as possible to the inside melter wall to allow the greatest amount of access to the glass inside of the melter.

3) Removal of Deposits from Inside of Melter Lid

As stated before, there is a chance that the melter lid refractories were removed when SGM was shutdown in the late 1980's. If the refractories are still there, the lid will have to be flipped and tools such as a diamond wheel shaver, needle scaler, a rotary tool with a face grinding wheel, or a needle gun will be tested remotely. If the lid refractory is missing, this task can be performed on the Mullfrax 202 refractory located in the SGM above the melt line.

The tool used should be able to just clean the deposits on the surface of the refractory without taking out much of the refractory itself. Care will need to be taken to not damage the refractory so that the melter cannot be reused for vitrification work in the future.

\section{4) Glass Breakup /Removal from the Melt Pool}

The SGM was drained before being shut down so there is only a thin layer of glass on the bottom of the melter. To perform this task a shallow pan that has a diameter that is slightly less than the inner diameter of the melter will be filled with glass and lowered into the melter. If possible, glass could be filled directly into the melter to be broken up. The pan will have to be held in place so that it does not move during the glass breakup work.

The candidate tools for this remote work will probably be a type of jack hammer/chisel or a needle gun. Glass is fairly strong in compression and therefore the forces needed to breakup the glass may be high. Once a break in the glass is formed the work should be easier. After sufficient testing has been performed, techniques to remotely pick up the glass be tested as well. These techniques may include vacuums and a modified grapple. After this work, the glass pan (if used) will be removed. If there is sufficient glass on the melter floor from the melter draining, then some additional testing of glass breakup on this material should be performed as well. If this is done, care should be taken to not damage the K-3 floor refractory.

\section{5) Glass Removal from K-3 Refractory Surfaces}

There is a thin layer of glass on the K-3 refractory that was in contact with the melt pool. The candidate tools for this remote work will be a diamond wheel shaver, needle scaler, rotary tool with a face grinding wheel, or a needle gun. Care must be taken as to not 
damage the refractory past the point where the melter can be used for possible future vitrification work. After sufficient testing has been performed, it is suggested that techniques to remotely pick up the glass be tested as well.

6) K-3 Refractory Breakup

The K-3 refractory in the SGM cannot be broken up. K-3 pieces will be supplied by the PI or bought by the test site to perform remote breakup testing. The candidate tools are a jack hammer/chisel or a rotary tool with a face grinding wheel. The refractory will be held in place by some means for one series of testing and then attempts will be made to breakup refractory that is not held in place.

\section{7) Other Tasks}

Additional tasks can be demonstrated as deemed appropriate (by the PI and the test site) and within schedule and budgetary constraints. After completion of the demonstration, the SGM dome heaters will be replaced, the melter lid put back on the melter, and the lid then bolted in place.

\section{CONDUCT OF RESEARCH}

The work performed under this plan is to be considered scoping in nature (per SRTC Manual L1 - Procedure 7.10 "Control of Technical Work") and therefore the only required quality assurance documentation are an experimental plan and a notebook to record the work performed.

The test site will have designated point(s) of contact that the PI will correspond with during the planning and performance parts of all three stages of the demonstration. Additional records such as drawings of test equipment, documented agreements on changes to this experimental plan, and other information will be kept as well and will be turned over to the PI by the end of the demonstration.

Safety and Industrial Hygiene guidelines from the test sites performing the work will be followed.

\section{REFERENCES}

1. B. S. Richardson, "Melter Glass Removal and Dismantlement" USDOE Report ORNL/TM-2000/324, Oak Ridge National Laboratory, September 2000.

2. "Recommended Methods for Decontamination and Decommissioning, Size Reduction, and Disposal of Melter and Components - Evaluation Report", West Valley Nuclear Services, February 28, 2001 (no author or document number cited).

3. M. E. Smith, D. F. Bickford, F. M. Heckendorn, "Conceptual Methods for Decontamination and Decommissioning, Size Reduction, and Disposal of the DWPF Melter and Components (U), USDOE Report WSRC-TR-2001-00248, June 1, 2001. 
4. J. D. Gutmann, Jr., "DWPF Glass Melter Technology Manual (U), USDOE Report WSRC-TR-93-587 (rev. 0), November 5, 1993.

5. A. F. Weisman, "Design Comparison of the Scale Melter to the DWPF Melter (U), USDOE Report DPST-87-688, October 7, 1987. 
WSRC-RP-2001-00783

APPROVALS

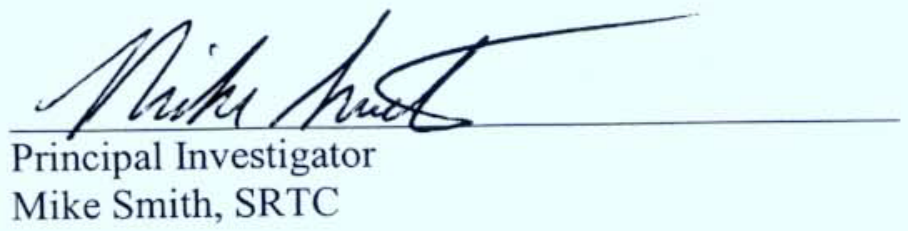

En blatzohut

TFA TIM and SRTC Derivative Classifier Level 3 Manager, ITS, SRTC

E. W. Holtzscheiter

Solano

Level 4 Manager, ITS, SRTC

Glass Formulation and Melter Technology

S. L. Mora

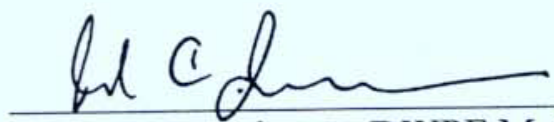

Technical Reviewer, DWPF Melter Cog Engineer D. C. Iverson
$8 / 16 / 01$

Date

$8 / 16 / 01$

Date

$8 / 21 / 01$

Date

$\frac{8 / 20 / 01}{\text { Date }}$

$8 / 16 / 01$

Date

$8 / 16 / 01$

Date

S. Killough

12 
WSRC-RP-2001-00783

\section{ATTACHMENT}

\section{FIU/HCET SCOPING TEST PROPOSAL}




\section{Demonstration and Evaluation of Potential Glass-Fracturing Technologies for Savannah River Site}

Proposal submitted to

\section{Tanks Focus Area U.S. Department of Energy}

July 17, 2001

Prepared by

HEMISPHERIC CENTER FOR ENVIRONMENTAL TECHNOLOGY

(HCET)

Florida International University, Center for Engineering \& Applied Sciences 10555 West Flagler Street, EAS-2100, Miami, Florida 33174 305-348-4238 • FAX: 348-1852 • World Wide Web Site: http://www.hcet.fiu.edu

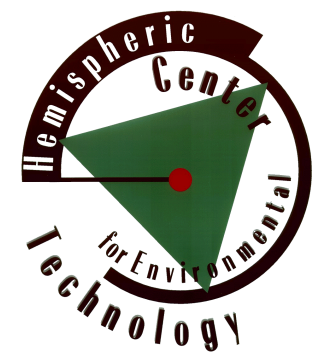




\section{PROPOSAL}

\section{Demonstration and Evaluation of Potential Glass-Fracturing Technologies for Savannah River Site}

Trey Buttelmann, Hans Weger, and Rajiv Srivastava

Project Investigators (Key Personnel)

Hemispheric Center for Environmental Technology

Florida International University

10555 West Flagler Street, Suite 2100

Miami, FL 33174

M. A. Ebadian

Principal Investigator

Hemispheric Center for Environmental Technology

Florida International University

10555 West Flagler Street, Suite 2100

Miami, FL 33174

Proprietary Notice. This document contains trade secret and commercial or financial information, which is proprietary to Florida International University's Hemispheric Center for Environmental Technology. Pursuant to the protection accorded by the Freedom of Information Act [5 USC 552(b) (4)], as amended, and the provisions of 18 USC 1905, it must at all times be treated as privileged and confidential and not to be duplicated, used or disclosed, in whole or in part, for any purpose except as specifically authorized by the Hemispheric Center for Environmental Technology in writing. The data subject to this restriction are contained in the sheets marked with a proprietary legend. 


\section{TABLE OF CONTENTS}

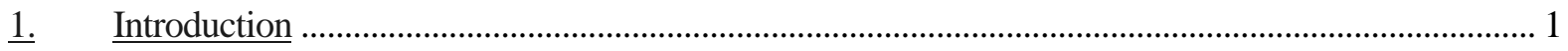

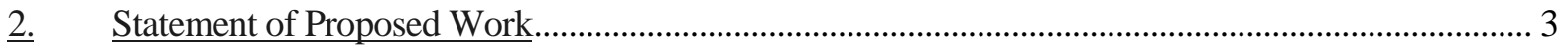

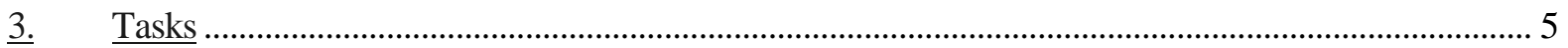

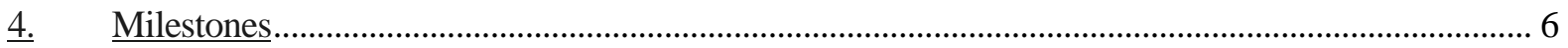

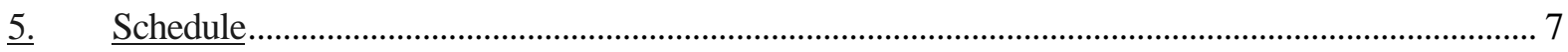

6. Quality Assurance Statement and Safety Measures ………................................................................. 8

7. Biographical Sketches of Key Personnel........................................................ 9 


\section{Introduction}

A primary, ongoing mission at the Savannah River Site (SRS) is to immobilize 35 million gallons of high-level liquid waste (HLW) produced over the past 45 years. Since March 1996 the DWPF has been using the vitrification technology to treat and immobilize radioactive sludge waste. Vitrification is the process of encapsulating radioactive waste in glass. Immobilization of the HLW is accomplished at the site's Defense Waste Processing Facility (DWPF).

Sludge batches are chemically treated with formic and nitric acid and mixed with borosilicate glass frit in a series of process tanks to make the sludge slurry suitable for melter feed. Feed slurry is pumped to the joule-heated melter (Fig. 1), where the water is flashed off and the sludge/glass frit mixture forms a crust over the melt pool. The crust, or cold cap, melts from the bottom and forms a liquid borosilicate glass matrix. The melt pool temperature is maintained at about $1150^{\circ} \mathrm{C}$ by controlling two pair of submerged electrodes passing current through the melt.

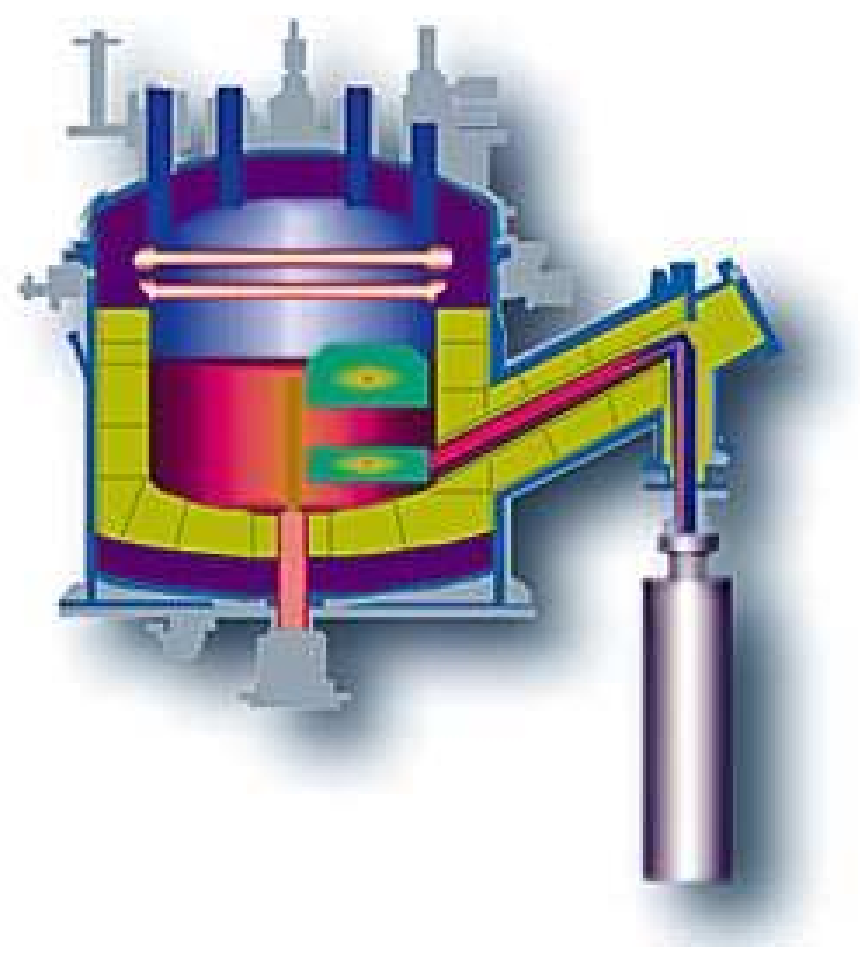

Figure 1. DWPF Melter

Throughout the continuous operation of pouring the glass/HLW melt, there is a decrease in the melt temperature. This decrease in temperature is primarily due to the settling of heavy metals from the HLW to the bottom of the melter. This increase in heavy metal concentration thereby decreases the overall resistance of the melt. As a product of this situation, there is an increase in the current passed 
between the electrodes, and a considerable decrease in temperature. This decrease causes the melt to begin to solidify. Once it has begun to take the solid glass matrix, the melt cannot be removed from the melter through the drain line or by pouring. This can lead to a shutdown of HLW processing operations, as well as extensive downtime attempting to remove this glass-waste compound from the melter interior.

A single failed glass melter, for example, could contain as much HLW glass as five canisters. It will contain additional contamination in the form of unmelted waste solids and as volatile cesium and ruthenium. It is unacceptable to place this "waste form" in relatively uncontrolled long term storage and to continue to add more of the same and other equipment. The current approach to dealing with this equipment is long term storage in the canyon facilities, on regulated storage pads or in underground "Failed Equipment Storage Vaults." While storage is acceptable for the short term, technology must be developed to properly dispose of this equipment. This should include dismantling/size reduction of the equipment, decontamination and recyling of as much material as possible, disposal of the majority of the material as low-level waste and disposal of remaining high level waste materials in a controlled repository or as a recycle stream to tank farms and ultimately the DWPF. 


\section{Statement of Proposed Work}

There is a need to demonstrate/develop innovative technologies that will assist in the removal of solidified glass from the melter tank. FIU-HCET will demostrate and evaluate up to six commercialy available hand-held tools for fracturing the glass matrix, refractory cleaning, and fracturing of the refractory. Technologies that have been identied are:

\section{A. Jack Hammer and Chisel (cutting tool)}
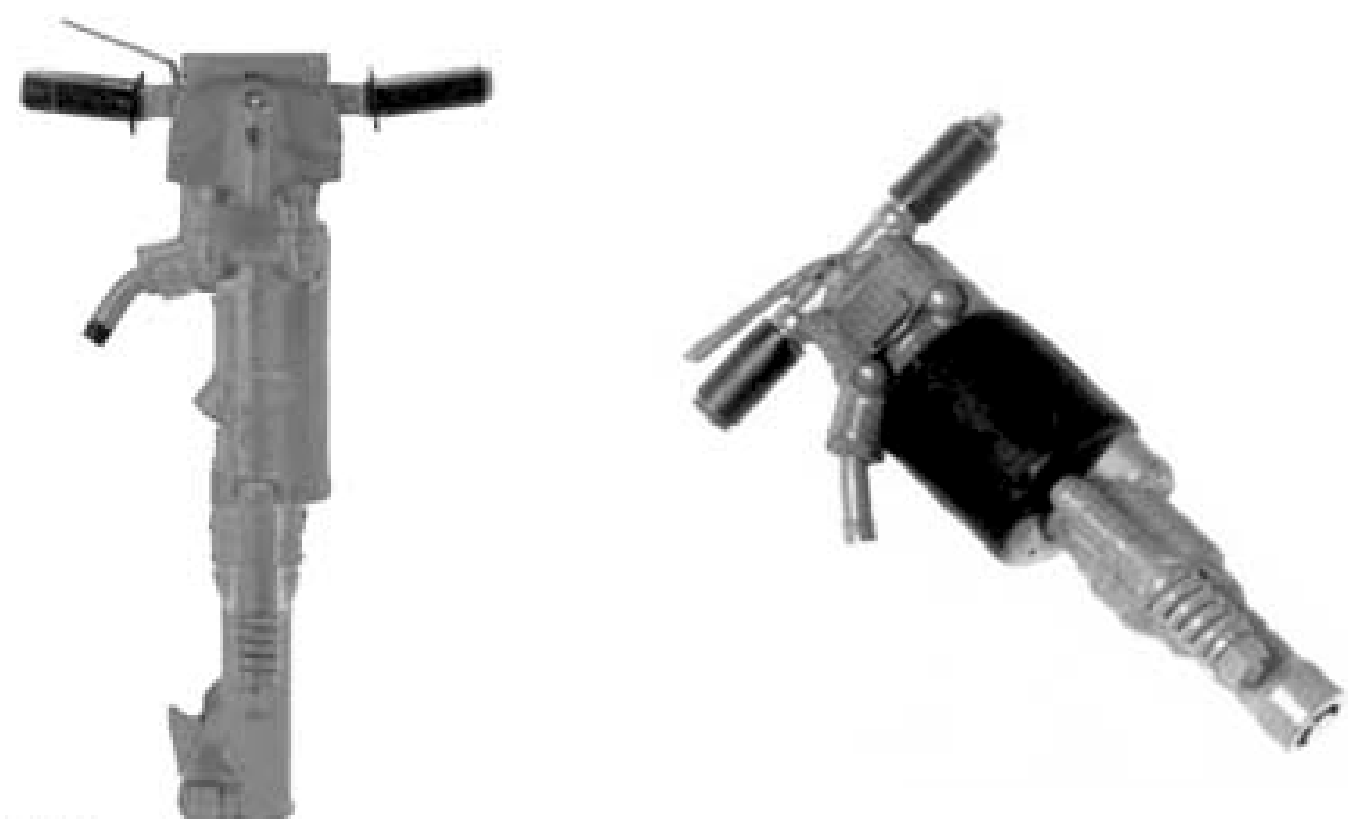

B. Needle-Gun

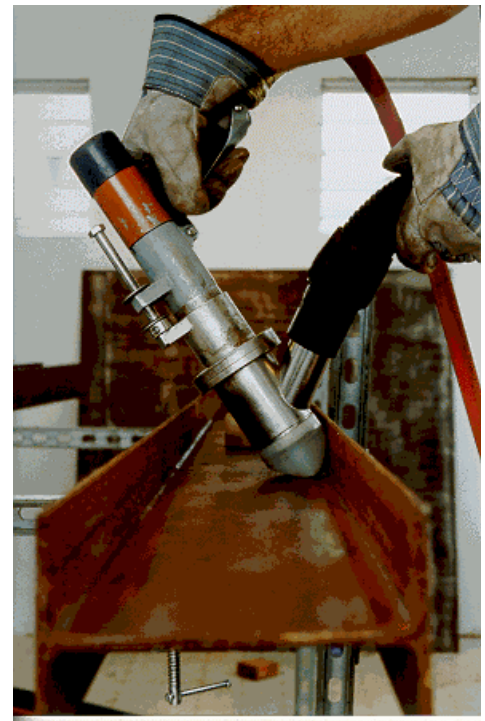




\section{Diamond Wheel Shaver}
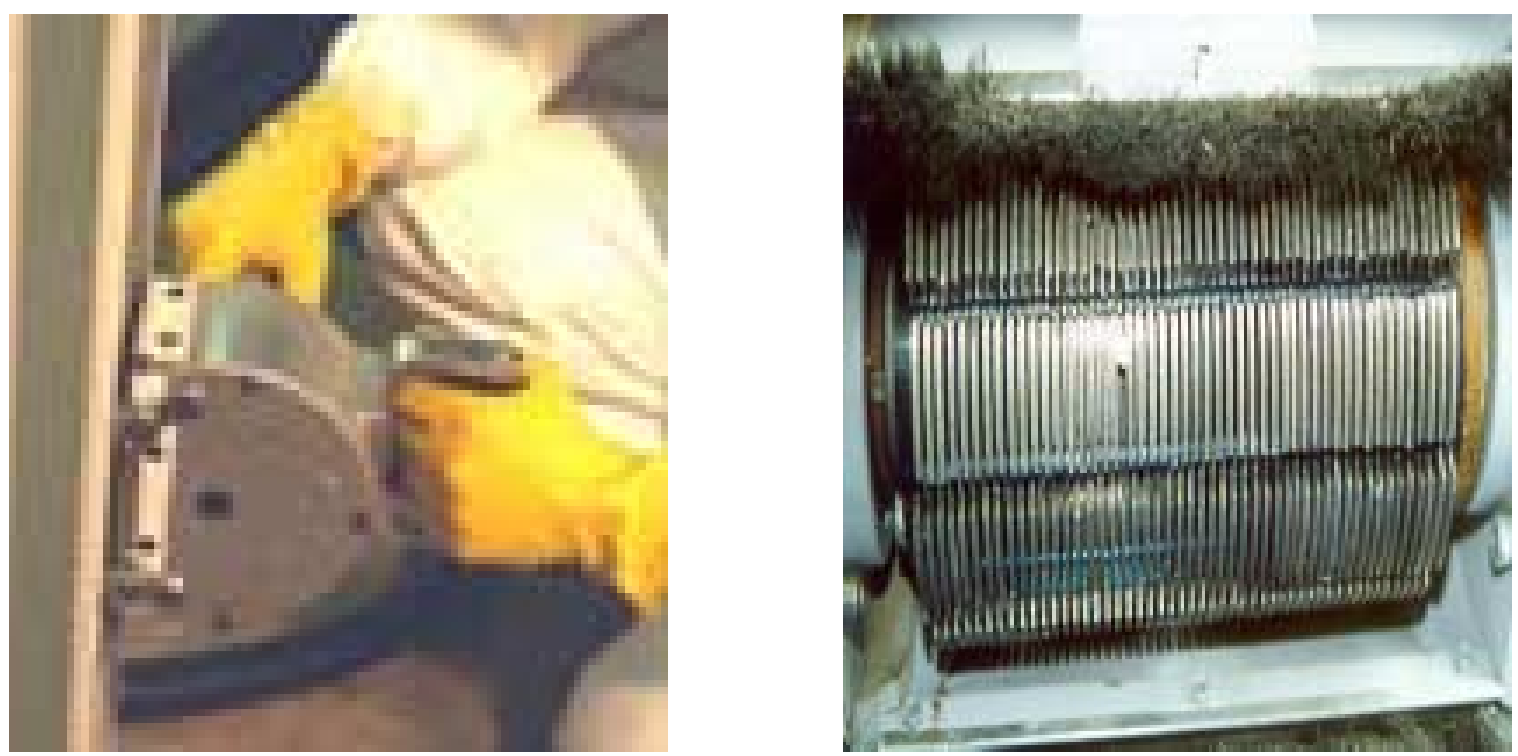

D. Needle Scaler
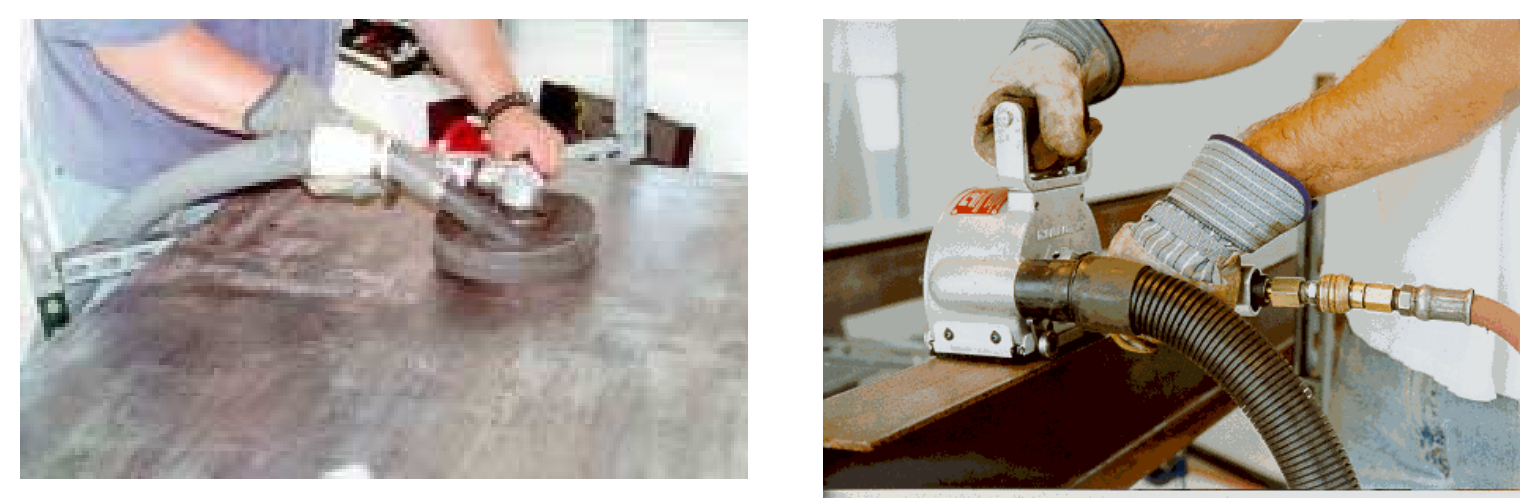

These technologies will be demostrated at the FIU-HCET facility in Miami and the tools will be leased for the demostrations. Surrogate (non-radioactive) glass will be developed by FIU-HCET for the technology demostration phase. Cost and performance data will be collected for each technology. In addition, photographs and videos will be used for capturing the performance of each technology. Labs books and field notes will be kept throughout the course of the project as per the FIU-HCET's Quality Assurance and Environmental Management System policy. A complete report will be provided to DOE-TFA at the end of this project. 


\section{Tasks}

FIU-HCET staff will provide technical services to support the activities described in this document. The tasks would include the following three activities:

\subsection{Development of a glass surrogate}

FIU-HCET will develop glass surrogate coupons for the technology demostrations. These coupons will be contained in 20 stainless steel containers. These containers will be at least $2 \mathrm{ft} \times 2 \mathrm{ft} \times 2 \mathrm{ft}$ and will be made out of $1 / 4$ " metal. The actual glass matrix composition will be provided by SRS. FIUHCET team will use existing facilities (melter) to melt the surrogate glass (provided earlier by SRS for an unrelated melter project). Metal oxides will be added to the containers and then filled with molten glass. This should result in a glass matrix rich with heavy metals at the bottom of the containers. The containers will be cooled to ambient temperature. As mentioned earlier, five commercially available tools will be demostrated; therefore, four containers will be available for each technology demostration. This should provide adequate number of samples for data collection and analysis.

\subsection{Demonstration of applicable tools and technology}

For technology demonstration purposes, a one to two days vendor's on-site training may be required tfor safety traing of HCET personnel towards use of the power tools. It is expected that the demostrations will last at least one week per technology. Field data will be collected on standard lab notebook and additional photos and videos will be use for recording these demostration. A complete data package will be collected during the execution of this task, including data on the forces exerted by the jack hammer and chisel.. FIU-HCET will encourage the presence and participation of SRS personnel during the technology demostration phase.

The tests will be divided into three subtasks:

1. Glass breakup: jack hammer/chisel and needle gun.

2. Removal of glass from K-3 refractory surface: diamond wheel shaver, needle scaler, and needle gun+.

3. K-3 breakup: jack hammer/chisel and a rotary tool with a face grinding wheel. 


\section{Milestones}

4.1 Complete development of glass surrogates using formulation provided by SRTC 11/01/01

4.2 Complete draft of mid year report

$04 / 30 / 02$

4.3 Delivery of draft year end report to SRS for review

$10 / 30 / 02$ 


\section{Schedule}

\begin{tabular}{|c|c|c|c|c|c|c|c|c|c|c|c|c|c|c|c|c|c|}
\hline \multirow[b]{2}{*}{ D } & \multirow[b]{2}{*}{ Tass Nene } & \multicolumn{16}{|c|}{2002} \\
\hline & & $\mathbf{A}$ & 5 & 0 & $\mathrm{~N}$ & D & $\sqrt{3}$ & $\mathrm{~F}$ & 显 & A & M & J & J & 4 & S & 0 & h \\
\hline 1 & Demonstration and Evaluation of Potential Glass Frachuring Technologies for SPS & & & & & & & & & & & & & & & & \\
\hline 2 & Development of the SAS Glass Surrogate & & & & & & & & & & & & & & & & \\
\hline 3 & Conplete developnent of glass surrogites: & & & & & & & & & & & & & & & & \\
\hline 4 & Demongtrabion of appicable tools and technology & & & & & & & & & & & & & & & & \\
\hline 5 & Class breakup & & & & & & & & & & & & & & & & \\
\hline 6 & Remonal of glass tromif-a netractary surface & & & & & & & & & & & & & & & & \\
\hline 7 & Complete draft of mid year report & & & & & & & & & & 4 & & & & & & \\
\hline 8 & L3treatop & & & & & & & & & & & & & & & & \\
\hline 9 & Tharmestation of Fear Find Bepot & & & & & & & & & & & & & & & & \\
\hline 10 & Defwery of dratl year end report to SRS for review & & & & & & & & & & & & & & & & \\
\hline
\end{tabular}




\section{Quality Assurance Statement and Safety Measures}

The FIU-HCET Quality Assurance Program is based on integration of ISO 9001, DOE Order 5700.6C, and incorporates elements of ANSI/ASQ E4-1994. It has recently been revised to integrate ISO 14001 elements in common with ISO 9001 as a part of FIU HCET's recent certification to ISO 14001. Certification for FIU-HCET from a certified Registrar, is dated October 1, 2000, and constitutes the first university organization in the U.S. to have its Environmental Management System certified. FIU-HCET management quality policy charges all personnel with responsibility for the quality of their work and conformance with customer requirements as well as the internal quality and environmental policies and procedures. Techniques for meeting quality requirements are identified during project planning in a graded approach to ensure that greatest emphasis and resources are provided to the most critical processes and products. The quality assurance program will be part of the team working on this project and will regularly oversee various aspects of the quality assurance (e.g., design; document and data control; purchasing; product identification and traceability; process control; inspection and testing; control of inspection and test equipment, measuring and test equipment; handling, storage, packaging, preservation and delivery; control of quality records; quality audits). 


\section{Biographical Sketches of Key Personnel}

\section{Dr. Rajiv Srivastava \\ Program Manager}

Dr. Srivastava leads the research group that provides assistance to the DOE for transfer and immobilization of radioactive waste. Dr. Srivastava's specialties are fluids flow, chemical kinetics, combustion modeling, environmental remediation and process design and scale-up. He has worked for the Center for Commercial Applications of Combustion in Space (CCACS), where he designed and modeled water mist systems for fire suppression. His research work also includes study on particulate formation from fluoropolymer degradation under terrestrial and microgravity and gas-solid heterogeneous photocatalysis for degradation of volatile organic compounds (VOCs). He has coauthored journal and conference papers and is a member of the American Institute of Chemical Engineers, American Chemical Society, and the American Institute of Aeronautics and Astronautics (AIAA).

\section{Dr. Hans Weger Research Coordinator}

Dr. Hans Weger obtained his Ph.D. in nuclear engineering at the University of Illinois at Urbana-Champaign in 1994. His dissertation research was on plutonium(VI) chemistry with phosphate, performed at Argonne National Laboratory. After graduation, he researched the aqueous chemistry of curium at the Forschungzentrum (Research Center) Karlsruhe in Germany. Thereafter, he worked on the Plutonium Immobilization Project at the Pacific Northwest National Laboratory (Hanford). Dr. Weger began working for HCET in June, 1998.

\section{Mr. Trey Buttelmann WPR Project Manager}

Mr. Trey Buttelmann received his degree in Chemical Engineering from Texas Tech in 1997. After working in the catalyst development department at Ekzo Nobel in Houston for 1 year, Trey joined the HCET in June of 1998. He has worked on the waste glass vitrification project assisting SRTC and DOE-TFA research and successfully implement the innovative downspout inserts to alleviate the wicking problem. 